\title{
PENGEMBANGAN MODEL ECOTOURISM DALAM RANGKA PERTUMBUHAN HIJAU DI KABUPATEN WAKATOBI(2013)
}

\author{
Development Modelling of Ecotourism to Support Green Growth \\ in Wakatobi District (2013) \\ IHSYALUDDIN \\ ical_tomia@yahoo.com
}

\begin{abstract}
This research is aim at developingecotourism model to support green growth implementation. The objects of research is describe the potential resources in Wakatobi and to finds a model ecotourism based of ecological to support Green Growth. The research used Research and Development method. Data have been collected by conducting indepth interview, and focus group discussion (FGD). This research reveals that the resources might be potential to develop would ecotourism setting. These researchalso produced somefactors that wouldsupport the development of ecotourism by involving willingness on local community, goodunderstanding on tourism benefit, and no cultural constraints. Also the produced environment equilibrium and social justice.
\end{abstract}

Keywords: development, model, ecotourism, green growth

Kabupaten Wakatobi sebagai daerah yang sebagian besar wilayahnya adalah laut dengan memiliki sumber daya laut yang sangat berlimpah dengan keranekaragam spesies mahluk hidup, menjadikan sebagai sumber yang potensial bagi pengembangan pariwisata (ecotourism) yang menjanjikan. Ini merupakan tantangan tersendiri bagi pemerintah daerah Kabupaten Wakatobi untuk berkerja lebih keras dan serius dengan lebih banyak melakukan perubahanperubahan dan penggunaan modelmodel dalam rangka peningkatan kualitas pariwisata yang salah satunya adalah dengan mencari dan mengembangkan model ecotourism.

Ekowisata

(ecotoruism) merupakan salah satu strategi untuk mendukung konservasi sumber daya alam dan menyediakan sumber penghasilan bagi masyarakat di dalam dan sekitar kawasan tanam nasional. Ekoswisata merupakan salah satu bentuk pendekatan yang bersifat positif terhadap pembangunan berkelanjutan yang berbasis ekologis dalam rangka pertumbuhan hijau (green growth), namun bila perencanaan tidak tepat atau buruk, maka pariwisata yang direncanakan atau dilaksanakan akan memiliki efek negatif yang serius terhadap lingkungan dan masyarakat setempat. Dalam rangka mengantisipasi dampak negatif, mencegah atau mengurangi diperlukan sebuah pendekatan atau model yang tepat pada pengembangan ecotourism dalam peningkatan green growth.

Kabupaten Wakatobi berada di daerah Segi Tiga Karang Dunia, dengan

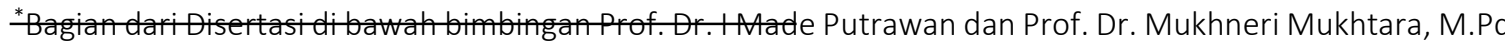
${ }^{* *}$ Swasta
} 
kekayaan biota laut yang berlimpah dan memiliki keindah yang luar biasa. Berdasarkan data hasil Rapid Ecological Assesment (AREA) oleh program bersama kelautan The Nature Conservancy - World Wide Fund (TNCWWF) (Anonim, 2008:7) bekerjasama dengan Balai Taman Nasional Kepulauan Wakatobi memiliki lebih dari 942 jenis spesies terumbu karang dan sekitar 590 jenis spesies ikan di Kepulauan Wakatobi. Dari 3 (tiga) pusat penyelaman kelas dunia, diketahui bahwa dari 850 jenis karang dunia, sekitar 90\% ditemukan di Wakatobi yakni 750 jenis karang.

Minimnya fasilitas, terutama masyarakat lokal didalam keterlibatan untuk menyediakan fasilitas, baik itu peralatan-peralatan penyelaman, fasilitas penginapan dan transportasi yang memanfaatkan transportasi masyarakat lokal. Juga kurangnya dorongan dan pendampingan yang maksimal untuk mengembangkan dan menciptakan industri rumah tangga, yakni berkaitan dengan pembuatan souvenir dan makan-makan khas Wakatobi.

Oleh karena itu, perlunya sebuah model untuk mengelola lingkungan dengan merumuskan persoalan biologis dan lingkungan fisik secara efektif. Salah satunya adalah dengan model pariwisata berbasis ecotourism. Dimana yang dimaksud dengan model adalah sebagai bentuk penyederhanaan dari bentuk realitasnya, yang merupakan satu kesatuan persamaan yang digunakan untuk memprediksi perilaku dengan satu variable atau beberapa variable (Barrow, 2006:189).

Wali dan kawan-kawan (2010:3) menjelaskan bahwa lingkungan merupakan keseluruhan yang ada di sekitar kehidupan kita.Oleh karena itu, manusia sebagai mahluk sosial yang selalu berinteraksi dengan lingkungan sekitarnya baik lingkungan biotic maupun lingkungan non-biotic, maka perlunya manajemen lingkungan yang tepat dalam memanfaatkan sumber daya alam dengan dapat meminimais dampak negatif dari aktivitasnya.

Evrendilek dan Fennesyseperti dikutip oleh Wali dan kawan-kawan (2010:4) mengatakan manajemen lingkungan adalah segala tindakan harus menerapkan prinsip-prinsip yang ramah lingkungan dan di dalam praktek untuk mengelola sumber daya alam, juga tidak lupa untuk dapat memecahkan masalah lingkungan dalam rangka menjamin kesejahteraan semua kehidupan termasuk manusia.Sedangkan Agarwal (2002:2) menjelaskan bahaw konsep manajemen lingkungan merupakan kegiatan atau aktivitas yang berkaitan dengan sumberdaya alam atau lingkungan yang berusaha untuk mengurangi atau mengunakan sumber daya alam yang ada semaksimal mungkin (minimais).

Selanjutnya Honey (1999:22-24) menjelaskan tentang ecotourism, yakni dia mengatakan bahwa ecotourism adalah perjalanan ke tempat yang rentan, murni, dan biasanya ke daerah lindung dengan berusaha mengurangi dampaknya dengan skala kecil. Membantu memberikan pendidikan ke para pelancong, menyediakan dana untuk konservasi; langsung bermanfaat pada pembangunan ekonomi dan politik didalam pemberdayaan masyarakat lokal, dan mendorong rasa hormat terhadap budaya yang berbeda dan hak asasi manusia.

Sedangkan Low (2011:3)
menyebutkan bahwa untuk
'pertumbuhan hijau' di satu sisi,
dikatakan kembali difokuskan pada


tantangan lingkungan dan sosial, dan di sisi lain, adalah kesadaran bahwa tujuan lingkungan dan ekonomi tidak saling eksklusif atau bertentangan.

Pada penelitian lain yakni yang dilakukan Garrod menemukan bahwa ekowisata semakin banyak mengalami kemajuan sebagai strategi untuk membantu mengatasi masalah ekonomi dan sosial dimasyarakat lokal, terutama di daerah-daerah yang dianggap perifer dalam konteks nasional maupun internasional. Hal ini, sering direkomendasikan sebagai alat yang cocok dan efektif untuk pelestarian lingkungan. Partisipasi yang penuh dan efektif dari masyarakat setempat dalam perencanaan dan pengelolaan ekowisata dalam proyeke kowisata. Paling buruk, proyek ekowisata dapat mengabaikan isu partisipasi lokal sepenuhnya, efektif masyarakat lokal terlibat dalam proses perencanaan dan manajemen pada pengembangan ekowisata.

Maka berdasarkan penjabaran di atas, dapat di rumuskan masalahanya adalah sebagai berikut; "Bagaimanakah model ecotourism dapat meningkatkan pertumbuhan hijau (green growth) di Kabupaten Wakatobi".

Penelitian ini bertujuan untuk dapat mengembangkan sebuah model ecotourism dengan memperhatikan kaidah-kaidah ekologis. Juga bertujuan untuk memperoleh gambaran tentang model ecotourism dalam rangka pelestarian lingkungan dan kesejahteraan masyarakat lokal, juga memperoleh gambaran kondisi lingkungan, sosial, budaya dan ekonomi dengan menggunakan $R$ \& $D$ untuk model ecotourism di Kabupaten Wakatobi

Penelitian ini menggunakan metode Research and Development (R \& D) yang diterapkan didalam pengembangan model ecotourism dalam rangka pertumbuhan hijau (green growth). Pengambilan data dilakukan melalui wawancara, focus group discussion (FGD) dan dokumen.

Proses dan kegiatan penelitian ini menempuh beberapa tahapan yang dapat dijelaskan sebagai berikut: Tahap pertama; Penelitian survei. Tahap kedua; Penelitian teoritik. Tahap ketiga; penyusunan model ecotourism berbasis ekologis. Tahap keempat; Validasi model. Tahap kelima; penilaian dan pengembangan model. Tahap keenam; Penyusunan Model.

\section{Hasil Penelitian dan Pembahasan}

Pada tahun 2003 berdasarkan Undang-Undang Nomor 29 Tahun 2003 tentang Pembentukan Kabupaten Bombana, Kabupaten Wakatobi, Dan Kabupaten Kolaka UtaraDi Provinsi Sulawesi Tenggara, Kabupaten Wakatobi dibentuk sebagai daerah otonom baru pemekaran dari Kabupaten Buton. Ditunjuk sebagai Kawasan Pelestarian Alam dengan status Taman Nasional melalui SK Kementan RI No:393/KptsVI/1996 tanggal 30 Juli 1996 dan ditetapkan melalui KepMenKehutanan No:7651/ Kpts-II/2002 tanggal 19 Agustus 2002 dengan luas kawasan 1.390.000 Ha.Deskripsi zonasi TNW mengacu pada Permenhut Nomor: P.56/Menhut-II/2006.

Kabupaten Wakatobi merupakan daerah kepulauan, luas kawasan Kepulauan dan perairan disekitarnya adalah 1.390.000 $\mathrm{Ha}$, dengan 97\% wilayah laut sedangkan sisanya $3 \%$ daratan. Memiliki pulau 138 buah. Secara geografis terletak di bagian selatan garis khatulistiwa. Kabupaten Wakatobi terdiri dari 8 Kecamatan yaitu; Binongko, Togo Binongko, Tomia, Tomia Timur, Kaledupa, Kaledupa Selatan, Wangi- Wangi, dan Wangi-Wangi 
Selatan. Dengan jumlah penduduk \pm 94.846 orang.

Jumlah tingkat pendidikan yang ditamatkan berdasarkan data sensus penduduk (Data Sensus Penduduk 2010, BPS RI). Dapat dilihat bahwa yang berpendidikan rendah (SLTP, SD, tidak tamat SD dan tidak pernah sekolah) yakni 82,39\%, sedangkan yang berpendidikan tinggi (SLTA/sederajat, diploma I/II/II, diploma IV/Universitas/S1 dan S2/S3) yakni $17,61 \%$. Artinya berdasarkan persentase data tersebut sumber daya manusia yang bisa andalkan dapat berproduksi berdasarkan jenjang pendidikan sangat rendah sekali.

Berdasarkan data Balai Taman Nasional Wakatobi potensi sumber daya alam yang dimiliki Kabupaten Wakatobi, yakni dipetakan dalam 8 (delapan) sumber daya penting wakatobi yang menjadi target kegiatan konservasi yakni terdari dari: 1) terumbu karang, 2) mangrove, 3) penyu, 4) burung pantai/laut, 5) tempat pemijahan ikan (SPAG'S), 6) ikan target/ikan karang, 7) lamun dan 8) cetacean. Wakatobi terletak di Jantung

Di bawah ini merupakan rangkuman data Dinas Pariwisata Kabupaten Wakatobi:

Potensi sumber daya alam berdasarkan Kecamatan di Kabupaten Wakatobi: 1) Kecamatan Wangi-Wangi dan Wangi-Wangi Selatan: a) Pantai(6 lokasi), b) Perairan Laut(5 macam potensi), c) Panorama Puncak/Perbukitan(2 tempat), d) Hutan (2 macam), e) Goa Air dan Telaga (3 lokasi), danf) Pulau-Pulau Tak Berpenghuni; 2) Kecamatan Kaledupa dan Kaledupa Selatan: a) Pantai(7 lokasi), b) Perairan Laut (5 macam potensi), c) Hutan (1 jenis), d) Goa,Telaga, Danau (6 tempat), e)
Panorama Bukit/Puncak (1 lokasi), f) Pulau-Pulau Tak Berpenghuni; 3) Kecamatan Tomia Dan Tomia Timur: a) Pantai (4 lokasi), b) Perairan Laut (4 macam potensi), c) Goa,Telaga(5 tempat), d) Panorama Puncak/ Perbukitan (2 tempat), e) Hutan (1 jenis), f) Pulau-Pulau tak Berpenghuni. 4) Kecamatan Binongko dan Togo Binongko: a) Pantai (6 lokasi), b) Goa Telaga (2 lokasi), c) Perairan Laut, d) Hutan Mangrove, f) Pulau-Pulau Tak Berpenghuni.

Potensi Obyek dan Daya Tarik Wisata (ODTW) Budaya dan Buatan, yakni 1) Kecamatan Wangi-Wangi dan Wangi-Wangi Selatan, meliputi :(Benteng Keraton Liya, Benteng Tindoi, Benteng Wabue-Bue, Kuburan Tua, Benteng Koba, Benteng Mandati Tonga, Benteng Watinti, Benteng Togo Malengo, Benteng Baluara, Mesjid Tua, dan Seni rupa). 2) Kecamatan Kaledupa dan Kaledupa Selatan, meliputi: Rumah Adat (kamali), Makam Imam Fada, Benteng Tobelo, Benteng Kamali, Benteng La Manungkira, Perkampungan Tradisi-onal Palea, Benteng La Donda, Benteng La Bohasi, Benteng Tapa'a, Mesjid Bente, Benteng Tua Ollo, Benteng Horuo, Situs Kampung Laulua, Benteng Olo). 3) Kecamatan Tomia dan Tomia Timur, meliputi: 1) Benteng Patua, 2) Benteng Suo-Suo. 4) Kecamatan Binongko dan Togo Binongko, meliputi: Benteng Wali, Koncu Kapala, Makam La Ode Simbo, Makam La Ode Sibi, Makam La Berese, Mesjid Wali I, Makam Wali Wangka Wijaya, Lia Mouse, Lia Ompu Patua, Makam Papalia, Baruga Sarano Wali I, Lia Bungka Bulawa (Gua Kepiting Emas), Benteng Palahidu, Benteng Oihu, Pengrajin Pandai Besi, Kau Rangka, Makam Wa Ode Goa, Benteng Fatima, Benteng Baluara, Benteng Haka, dan Benteng Tadu. 
Sarana dan Prasarana Pariwisata;
Data tahun 2007 terdapat: penginapan/hotel (179 buah), Prasarana angkutan laut berupa dermaga di WangiWangi; Pelabuhan (Wanci) sebanyak 2 pelabuhan (Panguhu Belo dan Mola), di Kaledupa, terdapat 1 dermaga di Ambeua, di Tomia, terdapat dua pelabuhan laut/dermaga di Waha dan Usuku, di Binongko, tersedia satu pelabuhan laut/dermaga. Prasarana trasportasi udara ada 3 buah yaitu di Tomia lapangan terbang Maranggo (milik PT Wakatobi Resort), di WangiWangi lapangan terbang Matahora (miliki Pemda) telah beroperasi, dan di
Kaladeupa Desa Sombano dalam tahap pengerjaan.

\section{Organisasi}

(Kelembagaan)

Pariwisata di Kabupaten Wakatobi: Keterlibatan instansi pemerintah berdasarkan tugas, terkait pariwisata, yakni antara lain: 1) Dinas Kebudayaan dan Pariwisata 2) Balai Taman Nasional Wakatobi, 3) Dinas Perikanan dan Kelautan, 3) Bappeda, 4) Dinas Tata Ruang,5) Dinas PU dan Perhubungan, 6)Dinas Pendidikan. Juga memiliki: 1) WWF-Indonesia, 2) TNC, 3) LSM Cinta Karang, 3) LSM Sintesa Cabang Wakatobi, Forum Nelayan Pulau (FORKANI) Kaledupa, dll.

\section{Hasil Wawancara Penelitian}

Berdasarkan hasil di lapangan maka dapat disimpulkan sebagai berikut:

Tabel 1. Aspek-aspek Terkait dengan Pengembangan Model Ecotourism di Kabupaten Wakatobi

\begin{tabular}{|l|l|}
\hline \multicolumn{1}{|c|}{ Aspek } & \multicolumn{1}{c|}{ Keterangan } \\
\hline Sumber daya & $\begin{array}{l}\text { - Peningkatan SDM yang dilakukan pemerintah dan BTNW melalui } \\
\text { lokarkarya, workshop, studi banding } \\
\text { - Peningkatan ekonomi kreatif terutama berkaitan dengan } \\
\text { pariwisata baru dilakukan akhir-akhir ini }\end{array}$ \\
& $\begin{array}{l}\text { - Masyarakat melihat prospek pariwisata belum menjanjikan } \\
\text { - Kebanyakan tenaga kerja lokal hanya berperan sebagai pekerja } \\
\text { kuli (tukang sapu, pelayanan, operator kapal dll) }\end{array}$ \\
\hline - Pemerintah (kecamatan) minim informasi atau pengetahuan \\
tentang potensi dan kelembagaan dalam pedataan potensi- \\
potensi di wilayahnya
\end{tabular}




\begin{tabular}{|c|c|}
\hline Aspek & Keterangan \\
\hline & $\begin{array}{l}\text { perubahan. Walaupun masih ada perilaku masyarakat dalam } \\
\text { menambang pasir sehingga terjadi abrasi. } \\
\text { - Upaya perbaikan/penanaman karang belum ada, baru sekedar } \\
\text { sampai pada penelitian dan pelarangann penambangan } \\
\text { - Ada beberapa jenis burung (hewan) mengalami penurunan } \\
\text { akibat perburuan, dll }\end{array}$ \\
\hline $\begin{array}{l}\text { Sarana prasana / } \\
\text { infrastruktur }\end{array}$ & $\begin{array}{l}\text { - Infrastruktur belum memadai / masih banyak yang kurang } \\
\text { - Informasi tentang lokasi atau tujuan minim dan tidak ada sama } \\
\text { sekali, transportasi tidak memadai (angkutan darat) } \\
\text { - Standar penginapan pada prinsipnya sudah lumanyan } \\
\text { - Fasilitas penyelaman masih sangat terbatas }\end{array}$ \\
\hline $\begin{array}{l}\text { Stakeholder / } \\
\text { Lembaga mitra }\end{array}$ & $\begin{array}{l}\text { - Pemerintah, stakeholder dan masyarakat berusaha menciptakan } \\
\text { suasana rasa nyaman dan kesan yang baik bagi pariwisata } \\
\text { - Masih lemahnya koordinasi (komunikasi) antar } \\
\text { lembaga/forum/instansi dan masyarakat di Wakatobi, terutama } \\
\text { yang langsung bersentuhan dengan sumber daya laut belum } \\
\text { terbangun dengan baik. }\end{array}$ \\
\hline $\begin{array}{l}\text { Kebijakan } \\
\text { ecotourism }\end{array}$ & $\begin{array}{l}\text { - Prioritas pengelolaan lingkungan di Wakatobi adalah Pariwisata } \\
\text { dan Perikanan } \\
\text { - Arah kebijakan lebih banyak mengarah kepada sumber daya laut. } \\
\text { Juga Koordinasi antar institusi dalam program terutama } \\
\text { pariwisata tidak terbangun dengan baik } \\
\text { - Pelibatan masyarakat dalam pengontrolan pengelolaan } \\
\text { lingkungan (laut) } \\
\text { - Ada indikasi politisasi berkaitan dengan pengembangan } \\
\text { ecotourism (pariwisata) di wakatobi } \\
\text { - Persoalan implementasi menjadi kendala baik itu datang dari } \\
\text { pemerintah daerah, stakeholder maupun masyarakat }\end{array}$ \\
\hline $\begin{array}{l}\text { Pengembangan } \\
\text { usaha }\end{array}$ & $\begin{array}{l}\text { - Pemerintah membentuk kelompok-kelompok desa wisata namun } \\
\text { masih minim staf/pedamping ( } 3 \text { org/desa) } \\
\text { - Antar promosi dan kenyataan dilapangan jauh berbeda } \\
\text { - Kegiatan atau even belum maksimal dan jarang dilakukan } \\
\text { didaerah/dikampung-kampung } \\
\text { - Masyarakat belum berminat dalam pengelolaan pariwisata, } \\
\text { karena kurang modal, kebiasaan (mindset), Juga masih belum } \\
\text { maksimalnya penyuluhan /palatihan } \\
\text { - Ada praktek monopoli pada pengelolaan pariwisata di wakatobi }\end{array}$ \\
\hline
\end{tabular}

Hasil Diskusi / Focus Group Discussion (FGD) 
Berdasarkan hasil Focus group discussion (FGD) makan dapat di rangkum dalam tabel saebagai berikut:

Tabel 2. Aspek-aspek Terkait dengan Pengembangan Model Ecotourism dalam Pertumbuhan Hijau di Kabupaten Wakatobi

\begin{tabular}{|c|c|}
\hline Aspek & Keterangan \\
\hline Sumber daya & $\begin{array}{l}\text { - Pemda terutama pegawai tidak banyak paham dengan konsep } \\
\text { ecotourism. } \\
\text { - Kurangnya pemahaman atau tidak adanya keseriusan untuk } \\
\text { dapat mengindentifikasi dan memahami nilai-nilai yang ada } \\
\text { dimasyarakat demi menciptakan dan mendukung kegiatan } \\
\text { pariwisata yang lebih mengarah pada kegiatan pengembangan } \\
\text { kawasan ecotourism. } \\
\text { - Kurangnya pengetahuan para guide/pemandu turis tentang } \\
\text { potensi, kondisi lingkungan fisik dan budaya setempat. } \\
\text { - Pola pikir masyarakat masih belum paham dengan peluang dan } \\
\text { pengembangan desa wisata yang dikembangkan oleh Balai } \\
\text { Taman Nasional }\end{array}$ \\
\hline $\begin{array}{l}\text { Pengembangan } \\
\text { potensi }\end{array}$ & $\begin{array}{l}\text { - Pemerintah hanya berkutat pada program fisik sarana dan } \\
\text { prasarana akan tetapi program pengembangan sosial, ekonomi } \\
\text { dan juga budaya sangat kurang. } \\
\text { - Pemerintah gagal memberikan pelayanan yang maksimal yang } \\
\text { dapat menciptakan kondisi/imeg yang baik bagi pelayanan dan } \\
\text { kesan untuk dapat dinikmati oleh para wisatawan } \\
\text { - Pemetaan potensi yang belum jelas, selama ini hanya berfokus } \\
\text { pada pemanfaatan sumber daya alam laut /underwater, ini pun } \\
\text { juga belum maksimal. } \\
\text { - Konsep belum maksimal dari isi kegiatan pengembangan model } \\
\text { ecotourism yang ditawarkan }\end{array}$ \\
\hline $\begin{array}{l}\text { Peningkatan } \\
\text { kualitas } \\
\text { lingkungan }\end{array}$ & $\begin{array}{l}\text { - adanya praktek/indikasi pemberian izin pengelola sumber daya } \\
\text { laut tidak tepat sasaran. Kurangnya pangawasan/control yang } \\
\text { dilakukan pihak terkait terhadap sumber daya laut di wakatobi } \\
\text { - Pengelola/penambangan pasir masih dilematis disisi lain pasir } \\
\text { merupkan bahan dasar membangun disisi lain tidak ada } \\
\text { alternative untuk mengganti pasir sebagai bahan dasar } \\
\text { bangunan. Sehingga penambagnan pasir akan terus berjalan } \\
\text { yang akan membuat terjadinya abrasi dipantai dbeberapa } \\
\text { daerah. }\end{array}$ \\
\hline $\begin{array}{l}\text { Sarana prasana / } \\
\text { infrastruktur }\end{array}$ & $\begin{array}{l}\text { - Pemanfaatan infrastruktur yang belum maksimal } \\
\text { - Banyaknya lokasi sejarah dan daerah-daerah natural yang } \\
\text { disulap atau dikelola secara tidak profesional yang pada akhirnya } \\
\text { merusak nilai dari tempat atau lokasi-lokasi tersebut } \\
\text { - Pemerintah lebih berfokus pada penyedian infrastruktur yang } \\
\text { modern yang banyak dikelola oleh orang-orang tertentu, tanpa }\end{array}$ \\
\hline
\end{tabular}




\begin{tabular}{|c|c|}
\hline Aspek & Keterangan \\
\hline & memanfaatkan sumber-sumber daya yang ada lokasi setempat. \\
\hline $\begin{array}{l}\text { Stakeholder / } \\
\text { Lembaga mitra }\end{array}$ & $\begin{array}{l}\text { - Tidak adanya koordinasi yang terbangun antar instansi } \\
\text { - Gap di masyarakat dalam pengembangan ekotourism masih } \\
\text { terasa. }\end{array}$ \\
\hline $\begin{array}{l}\text { Kebijakan } \\
\text { ecotourism }\end{array}$ & $\begin{array}{l}\text { - Tidak ada master plan atau planning yang jelas tentang } \\
\text { pengembangan ecotourism di wakatobi } \\
\text { - Tidak adanya program atau kegiatan yang bersentuhan langsung } \\
\text { dengan masyarakat berkaitan dengan kesiapan pariwisata } \\
\text { terutama pengelolaan lingkungan yang berbasis ekotourism, } \\
\text { terutama berbasis budaya maupun berbasis kemasyarakatan } \\
\text { (sosial) } \\
\text { - Banyak program tidak dimanfaatkan secara efektif dan tepat } \\
\text { sasaran. Kegiatan dilakukan secara serimonial semata dan } \\
\text { banyaknya program/proyek ke masyarakat dalam bentuk fisik } \\
\text { yang gagal. Ironinya terkesan proyek yang ada hanya untuk } \\
\text { memenuhi kepentingan-kepentingan kroni-kroninya. } \\
\text { - Tidak adanya perda tentang pengelolaan pariwisata } \\
\text { - Konsep pariwisata belum didukungoleh sarana dan prasarana, } \\
\text { implementasi kebijakan pariwisatabelum optimal. } \\
\text { - Konsep ecotourism masih bersifat konseptual belum bersifat } \\
\text { operasional.Implementasinya susah di lapangan. } \\
\text { - Politisasi/kepentingan politik berkaitan dengan pariwisatan dan } \\
\text { isu konservasi. } \\
\text { - Kebijakan bupati/visi, misi tentang pengembanganecotourism di } \\
\text { Wakatobi tidak dapat diimplementasikan oleh bawahannya } \\
\end{array}$ \\
\hline $\begin{array}{l}\text { Pengembangan } \\
\text { usaha }\end{array}$ & $\begin{array}{l}\text { - Pejabat secara personal terlibat sebagai agen/pelaku bisnis } \\
\text { dalam kegiatan pariwisata yang berkaloborasi/bekerjasama } \\
\text { dengan beberapa oknum pengusaha untuk menguasai semua } \\
\text { aspek kegiatan pariwisata. } \\
\text { - Adanya pengelolaan/pengadaan resort dimiliki pak Hugua } \\
\text { (bupati) meganggu kegiatan pariwisata di Hoga. } \\
\text { - Banyaknya kegiatan pemberdayaan yang tidak tepat sasaran, } \\
\text { salah satunya adalah pelatihan keterampilan ibu-ibu yang ikut } \\
\text { adalah para istri pejabat atau kroninya. } \\
\text { - Potensi di darat dominan dinas pariwisata (berkaitan proyek- } \\
\text { proyek fisik) } \\
\text { - Pemanfaatan desa lingkungan selama ini belum di kembangkan } \\
\text { dan komuikasi antara pengelola dengan pemerintah belum } \\
\text { terbangun }\end{array}$ \\
\hline
\end{tabular}


Berdasarkan hasil Focus Group Discussion (FGD) tersebut di atas, pada prinsipnya adalah perlu adanya keseriusan dalam artian bahwa pengembangan ecotourism merupakan tawaran yang tidak dapat di sangkal untuk dikembangkan oleh semua pihak. Namun dari segi kebijakan harus diperbaiki, koordinasi antar lembaga/instutusi di tata ulang, keterlibatan masyarakat secara penuh, dan lain-lain. Hubungan kemitraan dengan perbankan/koperasi/pengusaha tidak pernah terbangun, maka kedepan perlunya di bangun demi mendukung pengembangan ecotourism secara maksimal.

\section{Pembahasan dan Pemetaan Model Ecotourism}

Ecotourism yang dikembangkan di kawasan konservasi adalah ecotourism yang "Green Growth" untuk kepentingan pembangunan berkelanjutan dan konservasi, yaitu sebuah kegiatan usaha yang bertujuan untuk menyediakan alternatif ekonomi secara berkelanjutan bagi masyarakat di kawasan yang dilindungi, berbagi manfaat dari upaya konservasi secara layak (terutama bagi masyarakat yang yang wilayah matapencahariannya yakni laut/nelayan dan sumberdaya alamnya berada di kawasan yang dilindungi).

Kriteria yang harus dilakukan oleh pihak pengambil kebijakan ataupun pihak-pihak yang terlibat dalam pengembangan ecotourism di Wakatobi, yakni: a) Prinsip daya dukung lingkungan diperhatikan dimana tujuan ekowisata dikelola sesuai dengan batas-batas yang dapat diterima baik dari segi alam maupun sosial-budaya; b) Sedapat mungkin menggunakan teknologi ramah lingkungan (listrik tenaga surya, mikrohidro, biogas, dll.); c) Mendorong terbentuknya "ecotourism conservancies" sebagai kawasan khusus pengelolaannya diberikan kepada organisasi masyarakat yang berkompeten; d) Mendukung dan mendorong kelompok-kelompok masyarakat, baik kelompok atau desa wisata maupun individu yang memiliki kemampuan untuk mengelola pariwisata berbasis ecotourism; e) Mempertimbangkan perilaku dan kebiasaan yang dilakoni masyarakat setempat (nelayan) selama ini.

Dengan adanya pola pariwisata berbasis ecotourism bukan berarti bahwa kepentingan lingkungan (ekologis) menjadi satu-satunya pertimbangan untukmelakukan kegiatan pariwisata. Namun didalam kenyataan pada implementasi ecotourism perlu dipandang sebagai bagian dari perencanaan pembangunan terpadu yang dilakukan di suatu daerah.Sehingga masyarakat, pemerintah, dunia usaha dan organisasi non pemerintah diharapkan membangun suatu jaringan dan menjalankan suatu kemitraan yang baik sesuai peran dan keahlian masingmasing. Pada akhirnya akan meningkatkan perekonomian (kesejahteraan) masyarakat dan peningkatan kualitas lingkungan. Juga keseimbangan ekosistem (ekologi) di Pulau Wakatobi yang dapat terlindungi.

\section{Analisi kebijakan ecotourism}

Kabupaten Wakatobi selain merupakan daerah otonom berdasarkan UU RI Nomor 29 Tahun 2003. Disisi lain juga merupakan kawasan Taman Nasional, SK Menteri Kehutanan RI Nomor: 393/Kpts-VI/1996. Sehingga antar kebijakan untuk mengembangkan daerah dengan pemanfaatan sumber daya alam wakatobi demi meningkatkan dan memajukan daerah bertentangan dengan kebijakan kawasan taman nasional, sebagai kawasan konservasi, 
yang merupakan kawasan yang tidak bisa eksploitasi dan bagaimana diupayakan untuk meminimalisir kerusakan lingkungan. Sedangkan Perda berkaitan dengan pengelola pariwisata khusus ecotourism belum ada sampai sekarang.

Oleh karena itu, diharapkan Misi pengembangan ecotourism Kabupaten Wakatobi adalah berbasis ekologis dengan berusaha mengelola lingkungan secara maksimal, dengan harapan adalah 1) Mengelola sumber daya alam berbasis pada kelautan, budaya dan pariwisata yang berwawasan lingkungan; 2) Pengembangan sistem ekonomi kerakyatan selaras dengan berkembangnya dunia usaha melalui kemitraan usaha ekonomi menengahdengan industri pariwisata dan kelautan/nelayan; 3) Terwujudnya kehidupan sosial yang dinamis dan berkembangnya seni budaya serta olahraga; 4) Terwujudnya kelestarian lingkungan hidup dan terkendalinya tata ruang wilayah; 5) Terwujudnyakeamanan dan ketertiban masyarakat; dan 6) Terwujudnya pemerintahan yang baik dan bersih (Good Governance).

Maka mestinya konsep

pengembangan ecotourisme dalam rangka peningkatan green growth di Kabupaten Wakatobi adalah: 1) Peningkatan sarana dan prasarana penunjang dikawasan wisata; 2) Meningkatkan promosi dan pemasaran wisata; 3) Pengembangan objek-objek wisata potensial utama site-site penyelaman; 4) Pengembangan objek wisata potensial Budaya dan lainnya; dan 5) pengembangan dan peningkatan sumber daya manusia.

Penelitian ini masih memiliki beberapa keterbatasansalah satunya adalah penelitian $R$ \& $D$ semestinya dilakukan dalam jangka waktu relatif lama dan melakukan uji coba model, jadi yang dilakukan oleh peneliti hanya sebatas pada penyusunan model. Juga Model ini belum merupakan model akhir, karena itu diperlukan penelitian lanjutan.

\section{Model ecotourism dalam rangka pertumbuhan hijau (green growth)}

Berdasarkan hasil dokumen, wawancara, FGD dan pembahasan tersebut di atas, maka dikembangkanlah konsep model terpadu pengembangan model ecotourism dalam rangka pertumbuhan hijau (green growth), yakni sebagai berikut: 


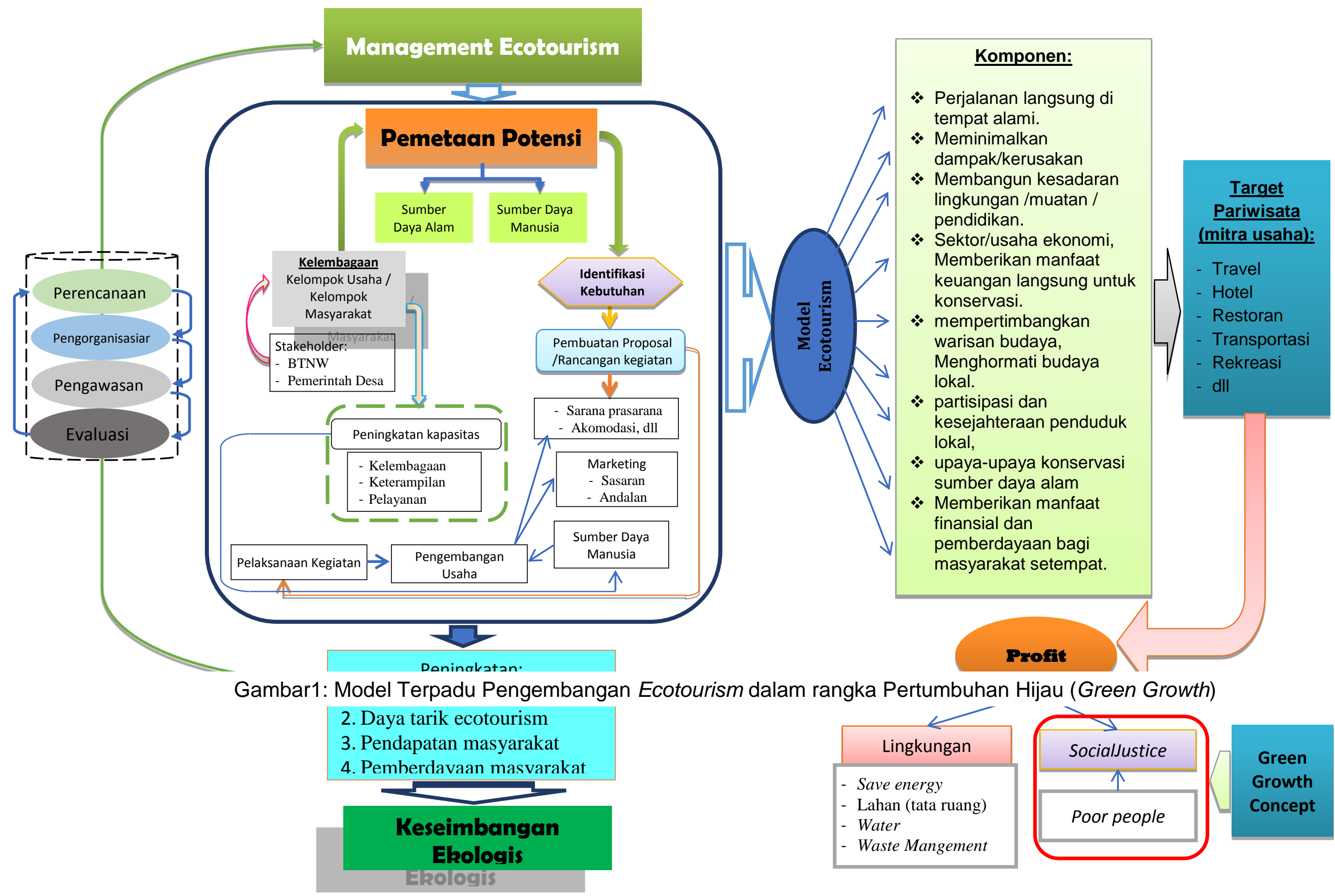




\section{Kesimpulan}

Potensi sumber daya laut dengan tingkat biodiversitas yang sangat kaya dimiliki Kabupaten Wakatobi. Maka strategi pengembangan model ecotourism merupakan model yang harus di jadikan landasan pengelolaan lingkungan dalam rangka pertumbuhan hijau (green growth) di kabupaten Wakatobi, sehingga tercipta keadilan sosial (kesejahteraan masyarakat lokal).

\section{Rekomendasi}

Berdasarkan kesimpulan dan penjelasan sebelumnya maka dapat di rekomendasikan dalam pengem-bangan model ecotourism agar tercapai pertumbuhan hijau (green growth). Maka perlu dilakukan atau upayakan adalah sebagai berikut: Pertama, aspek kebijakan: Pemerintah menciptakan kondisi yang baik bagi pengelola ecotourism di Wakatobi dengan perangkat peraturan yang mendukung dan mendorong peningkatan kegiatan ecotourism. Kedua, aspek koordinasi dan kelembagaan: Antara lembaga baik itu lembaga pemerintah maupun lembaga swasta bersama-sama masyarakat lokal terbangun dan saling mendukung dalam pengembangan ecotourism di Wakatobi. Ketiga, aspek sumber daya manusia: Pengelola dan masyarakat selalu meningkatkan kemampuan, skill, dan pengetahuan baik itu berkaitan dengan pengelolaan sumber daya alam (ecotourism), dengan dilakukan pelatihan, studi banding, peningkatan pendidikan secara konsisten dan berkala. Keempat, aspek insfrastruktur: Secara optimal dan memudahkan para pengunjung agar dapat menjangkau dengan mudah lokasi wisata, maka peningkatan penyedian infrastruktur yang masih sangat terbatas terutama informasi dan kemudahan transportasi antar pulau dan ditingkatkan kualitasnya. Kelima, aspek keilmuan; akan menambah dan peningkatan khazanah keilmuan tentang model ecotourism dalam rangka pertumbuhan hijau (green growth) dan juga diharapkan untuk dapat dilakukan penelitian lanjutan demi kesempurnaan model ecotourism.

\section{Daftar Pustaka}

Agarwal, S.K.Eco-Informatics: Environmental Management News Concepts. New Dehli: A.P.H. Publishing Corporation,2002.

Anonim.Visi Pemerintah Kabupaten Wakatobi: Terwujudnya Surga Nyata Bawah Laut di Jantung Segitiga Karang Dunia. Wangi-Wangi: Pemda Wakatobi, 2008.

Barrow, C.J. Environmental Management For Sustainable Development. New York: Routledge, 2007.

Data Sensus Penduduk 2010. BPS RI.

Garrod, Brian.Local Participation in the Planning and Management of Ecotourism: A Revised Model Approach. Faculty of Economics and Social Science. University of the West of England. Coldharbour Lane. Bristol. (http://users.aber.ac. uk/bgg/wp6.pdf)(diakses 08 Septem ber 2012).

Honey, Martha. Ecotourism and Sustainable Development: Who Owns Paradise?. Washington, DC: Island Press, 1999.

Low, Lit Ping.OECD, Green Growth and Developing Countries: A Summary for Policy Makers. June 2012.http://www.oecd.org /dac/50526354.pdf (di akses 21September 2012). 
Wali, Mohan K., Falih Evrendilek, dan M. Siobhan Fennesy. The Environment: Science, Issues, and Solutions. New York: CRC Press Taylor \& Francis Group, 2010.

Undang-Undang Nomor 29 Tahun 2003tentangPembentukan Kabupaten Bombana,Kabupaten Wakatobi, dan Kabupaten Kolaka UtaraDi Provinsi Sulawesi Tenggara, www.bpkp.go.id/uu/filedownload/2/40/274.bpkp, (di akses 12 Januari 2013). 